Waldemar Jaroch

\title{
WSPÓŁCZESNA ZORGANIZOWANA PRZESTĘPCZOŚĆ GOSPODARCZA
}

\section{Zagrożenia i współczesne formy przestępczości zorganizowanej}

W strukturze przestępczości gospodarczej już od lat dominują oszustwa gospodarcze (ponad 30\%). Obok oszustw gospodarczych, kolejną kategorię stanowią fałszerstwa gospodarcze (na poziomie 15\%), następne to przestępstwa przeciwko obrotowi gospodarczemu (tutaj obserwuje się spadek udziału w strukturze od 14,5\% do ok. 7\%) oraz przestępstwa przeciwko własności intelektualnej i przemysłowej (wzrost od 6,8\% do 10,2\%). Jest to pewna tendencja, która charakteryzuje strukturę przestępczości w świecie: sprzeniewierzenie aktywów, oszustwo, piractwo i podrabianie, korupcja i fałszowanie danych finansowych, pranie pieniędzy, wykorzystanie informacji poufnych do obrotu akcjami ${ }^{1}$.

Przestępczość gospodarcza, a ściślej przestępstwa gospodarcze, z uwagi na swą właściwość (związek z działalnością gospodarczą) ulegają permanentnym zmianom wraz ze zmianą warunków gospodarowania i pojawianiem się nowych możliwości działania w sferze gospodarczej. Dynamiczny postęp techniczny, postęp technologii komputerowych, nowe możliwości komunikowania się i nawiązywania transakcji, otwieranie kont bankowych i przeprowadzanie transakcji za pośrednictwem internetu stwarzają większe możliwości przestępnego działania. Nowe formy przestępstw wypierają tradycyjną przestępczość gospodarczą. Szczególne miejsce zajmuje obecnie przestępczość z wykorzystaniem technologii komputerowych, kształtując nowy wizerunek przestępczości, a mianowicie przestępczości internetowej. Lawinowy wzrost liczby przestępstw popełnianych z wykorzystaniem Internetu, a zwłaszcza oszustw na portalach aukcyjnych, jest egzemplifikacją zagrożeń, jakie wywołuje dynamiczny skok w rozwoju technologii informatycznych, dając szero-

$1 \quad$ Badania firmy PricewatershauseCooper oraz Uniwersytetu im. M. Lutra w Halle z 2003 i 2005 r. W roku 2005 poddano badaniu 3634 respondentów (przedsiębiorstw), w tym 101 z Polski. 
kie możliwości wykorzystania, w tym także przez struktury przestępcze. Jako przykład można wskazać chociażby przestępstwo phishingu, penalizowane przepisem art. 287 kodeksu karnego, a polegającego najogólniej ujmując na „wyłudzeniu” poufnych informacji osobistych (tzw. danych wrażliwych) dotyczących loginów, haseł, szczegółów rachunku bankowego, karty kredytowej, i nieuprawnionym dostępie do rachunków bankowych.

Tabela 1. Przestępstwa przeciwko obrotowi gospodarczemu

\begin{tabular}{|c|c|c|c|c|c|c|}
\hline Przestępstwa/Rok & 2008 & 2007 & 2006 & 2005 & 2004 & 2003 \\
\hline Pranie brudnych pieniędzy - art. 299 kk & 251 & 255 & 151 & 161 & 98 & 25 \\
\hline Oszustwa kredytowe - art. 297 kk & 10792 & 9101 & 8843 & 8045 & 5589 & 4869 \\
\hline Nadużycie zaufania - art. 296 kk & 185 & 237 & 680 & 501 & 650 & 770 \\
\hline $\begin{array}{c}\text { Oszustwo asekuracyjne - art. 298 kk } \\
\begin{array}{c}\text { Udaremnienie lub uszczuplenie } \\
\text { zaspokojenia wierzycieli }\end{array}\end{array} 1134$ & 150 & 196 & 162 & 125 & 178 \\
\hline $\begin{array}{c}\text { Doprowadzenie do upadłości } \\
\text { lub niewypłacalności }\end{array}$ & 46 & 53 & 75 & 92 & b.d. & b.d. \\
\hline $\begin{array}{c}\text { Usuwanie lub fałszowanie oznaczeń towarów } \\
\text { Udaremnienie przetargu }\end{array}$ & 970 & 887 & 1101 & 1652 & b.d. & b.d. \\
\hline & 18 & 19 & 15 & 45 & b.d. & b.d. \\
\hline
\end{tabular}

Źródto: www.policja.pl (skrót b.d. - brak danych w statystyce policyjnej).

Zagrożenie przestępczością identyfikowane jest w praktyce z liczbą ujawnionych przestępstw (przestępstw stwierdzonych), ale należy dodać, że w szczególności jeżeli chodzi o przestępczość gospodarczą, to skala ujawnionych przestępstw pozostaje w ścisłej relacji do stopnia zaangażowania organów w proces wykrywczy. Analizując dane w tym zakresie, stwierdzamy, iż w kategorii przestępstw przeciwko obrotowi gospodarczemu stałą tendencję rosnącą wykazuje oszustwo kapitałowe Z art. 297 kk. oraz przestępstwo prania pieniędzy z art. 299 kk. (zob. tab. 1). W pozostałych kategoriach przestępstw przeciwko obrotowi gospodarczemu obserwujemy tendencje spadkowe. Na uwagę zasługują przestępstwa, w stosunku do których obserwujemy wyraźną tendencję spadkową od roku 2006, jak przestępstwo nadużycia zaufania (z 680 w 2006 r. do 185 w 2008 r., spadek o 72,8\%), oszustwo asekuracyjne (ze 196 w 2006 r. do 134 w 2008 r., spadek o 31,6\%). Tendencje spadkowe odnotowujemy także względem przestępstw: usuwania lub fałszowania oznaczeń 
towarów (z 1652 w 2005 r. do 970 w 2008 r., spadek o 41,3\%), udaremniania lub uszczuplania zaspokojenia wierzycieli (z 1819 w 2005 r. do 1060 w 2008 r., spadek o 41,7\%), doprowadzenia do upadłości lub niewypłacalności (z 92 w 2005 r. do 46 w 2008 r., spadek o 50\%). Spadek liczby wskazanych przestępstw może wynikać z wielu przyczyn, np. rzeczywistego zmniejszenia stopnia zagrożenia tego rodzaju przestępczością, zwiększonym stopniem w zakresie przeciwdziałania (uszczelnianie procedur, zwiększony stopień kontroli), większą skutecznością w ściganiu tych przestępstw, ale może być też wynikiem mniejszego zaangażowania w proces wykrywczy tych przestępstw.

W zorganizowanej działalności przestępnej obserwujemy przeniesienie akcentu na zorganizowaną przestępczość gospodarczą i narkotykową, czyli te, które dają największe możliwości generowania przestępczych zysków. Ilustrują to dane Centralnego Biura Śledczego Komendy Głównej Policji (CBŚ KGP) dotyczące liczebności grup przestępczych w ujęciu rodzajowym w poszczególnych latach (zob. tab. 2).

Szczególne nasilenie spraw dotyczących zorganizowanych przestępstw ekonomicznych odnotowano już w 2002 r., kiedy stwierdzono wzrost liczby grup zajmujących się tą działalnością o $17,1 \%$ w stosunku do roku $2001 .^{2}$ Warto też zauważyć, że jeszcze do roku 2006 włącznie, najwięcej było grup ekonomicznych, a od 2007 roku prym wiodą grupy narkotykowe (tab. 2). Jako jedne z przyczyn zainteresowania sferą gospodarczą można wskazać nieszczelność prawa i możliwości przestępnego działania, zmianę pokoleniową w przywództwie grup przestępczych (inne spojrzenie oraz dostrzeganie innych źródeł dających zdecydowanie większe możliwości generowania zysków z przestępnej działalności).

Tabela 2. Struktura grup przestępczych wg wyodrębnionej kategorii

\begin{tabular}{|c|c|c|c|c|c|c|c|c|}
\hline Grupy wg kategorii/Rok & 2008 & 2007 & 2006 & 2005 & 2004 & 2003 & 2002 & 2001 \\
\hline Grupy ekonomiczne & 131 & 118 & 88 & 109 & 94 & 108 & 151 & 129 \\
\hline Grupy narkotykowe & 147 & 121 & 85 & 84 & 67 & 109 & 133 & 134 \\
\hline Grupy kryminalne & 103 & 74 & 49 & 66 & 66 & 90 & 178 & 159 \\
\hline Grupy multiprzestępne & 44 & 35 & 24 & 37 & 35 & 44 & 60 & 63 \\
\hline
\end{tabular}

Źródto: opracowanie własne na podstawie danych CBŚ KGP - raporty statystyczne.

2 Zob. Raport statystyczny Centralnego Biura Śledczego KGP z 2002 r.

* Grupy multiprzestępne - grupy zajmujące się wszelkimi rodzajami nielegalnej działalności (w zależności od okazji). 
Stwierdza się zatem zmiany jakościowe w zakresie obszarów zainteresowań i sposobów działania grup przestępczych. Potwierdza to także charakter postępowań procesowych prowadzonych przez Centralne Biuro Śledcze Komendy Głównej Policji w sprawach o przestępstwa gospodarcze (zob. tab. 3).

Tabela 3. Liczba i struktura spraw procesowych CBŚ KGP

\begin{tabular}{|c|c|c|c|c|c|c|}
\hline Rodzaj przestępstw / Rok & 2008 & 2007 & 2006 & 2005 & 2004 & 2003 \\
\hline Przestępstwa gospodarcze & 484 & 240 & 171 & 150 & 152 & 141 \\
\hline Przestępstwa narkotykowe & 547 & 189 & 180 & 146 & 155 & 139 \\
\hline Przestępstwa kryminalne & 539 & 245 & 237 & 188 & 144 & 141 \\
\hline Pranie pieniędzy & 123 & 88 & 99 & 81 & 70 & 54 \\
\hline Korupcja & 93 & 41 & 32 & 28 & 18 & 13 \\
\hline
\end{tabular}

Źródto: opracowanie własne na podstawie danych CBŚ KGP - raporty statystyczne.

Przechodząc do problematyki zagrożeń przestępczością gospodarczą, należałoby zwrócić uwagę na zakres pojęciowy tej przestępczości, bowiem w zależności od sposobu definiowania zróżnicowany będzie zakres i liczba przestępstw. Także w statystykach Centralnego Biura Śledczego KGP znajdujemy określenie „,przestępczość ekonomiczna”, obejmujące przestępstwo prania pieniędzy lub korupcję. ${ }^{3}$ Zgodnie bowiem z oficjalnym dokumentem Rady Europy „Legal Affaires, Economic Crime", wśród przestępstw gospodarczych wymienia się także przestępstwa komputerowe, fałszowanie pieniędzy i papierów wartościowych, przestępstwa giełdowe i bankowe, celne i szereg innych. Należy podkreślić, że brak definicji ustawowej przestępstwa gospodarczego oraz oparcie się na zakreśleniu zjawisk określanych jako przestępczość gospodarcza poprzez wskazanie konkretnych przestępstw powoduje, iż część z nich traci aktualność. Właściwe jest zatem skoncentrowanie się na danych Centralnego Biura Śledczego KGP, obrazujących zagrożenia poszczególnymi grupami przestępstw bądź konkretnymi przestępstwami, których wymiernym obrazem jest liczba prowadzonych przez CBŚ postępowań procesowych w sprawach o przestępstwa gospodarcze (zob. tab. 4). 
Współczesna zorganizowana przestępczość gospodarcza

Tabela 4. Postępowania wg kategorii przestępstw gospodarczych

\begin{tabular}{|c|c|c|c|c|c|c|}
\hline Przestępstwa / Rok & 2008 & 2007 & 2006 & 2005 & 2004 & 2003 \\
\hline Przestępstwa p-ko obrotowi gospodarczemu & 40 & 195 & 144 & 127 & 126 & 114 \\
\hline Przestępstwa z kodeksu karnego skarbowego & 90 & 45 & 27 & 23 & 18 & 27 \\
\hline Pranie pieniędzy & 123 & 88 & 99 & 81 & 70 & 54 \\
\hline Korupcja & 93 & 41 & 32 & 28 & 18 & b.d. \\
\hline Fałszerstwa środków płatniczych & 18 & 7 & 6 & 22 & 21 & 16 \\
\hline
\end{tabular}

Źródto: opracowanie własne na podstawie danych CBŚ KGP - raporty statystyczne; b.d. - brak danych.

W 2008 r. najwięcej postępowań odnotowano w sprawach o pranie pieniędzy (123), następnie w sprawach przestępstw z kodeksu karnego skarbowego (90), korupcji (93) i przeciwko obrotowi gospodarczemu (40).

W 2007 r. najwięcej postępowań stwierdzono w sprawach przestępstw przeciwko obrotowi gospodarczemu (195), przestępstw prania pieniędzy (88), przestępstw z kodeksu karnego skarbowego (45) i korupcji (41).

Analizując liczby prowadzonych postępowań w tych sprawach, można stwierdzić, że we wszystkich kategoriach mamy do czynienia z tendencją rosnącą, poza wyjątkiem incydentalnego spadku przestępstw przeciwko obrotowi gospodarczemu w 2008 r. Nie jest to zapewne stała tendencja wśród przestępstw przeciwko obrotowi gospodarczemu.

Zwalczanie przestępczości gospodarczej nierozerwalnie związane jest z aspektem ekonomicznym w postaci konkretnych strat z tytułu tej przestępczości. Przestępczość gospodarcza to straty dla Skarbu Państwa, społeczeństwa, grup społecznych, a tym samym w wymiarze indywidualnym - dla każdego potencjalnego klienta (konsumenta). Określenie tych strat jest czynnością stosunkowo trudną z uwagi na brak dokładnych danych, różne szacunki, często też brak publicznego udostępnienia tych danych. Stąd dla zilustrowania problemu posłużono się danymi odnoszącymi się do lat 2003-2004.

Według informacji Zespołu Prasowego Komendy Głównej Policji straty, nielegalny obrót, łapówki i uszczuplenia podatkowe w 2004 roku z tytułu przestępczości oszacowano na łączną kwotę 7,82 mld zł (7 821446423 zł), tj. 0,88\% Produktu Krajowego Brutto (PKB), z czego na przestępczość gospodarczą przypadło 3,97 mld zł (dokładnie: 3973396928 zł), co stanowiło 51\% łącznej kwoty strat i 0,45\% PKB. 
Z analiz statystyk kryminalnych wynika, żew ostatnich latach mamy do czynienia z ciągłą tendencją wzrostową w kilku kategoriach przestępstw, w tym głównie prania brudnych pieniędzy, oszustw kapitałowych (zob. tab. 1). Nielegalny obrót w 2004 r. na skutek przestępstw prania pieniędzy (z art. 299 kk.) oszacowano na 588269229 zł (0,588 mld zł) $)^{4}$; łapówki (przestępstwa z art. 228-231 kk., 250a kk., 296a-b kk.) oszacowano na 9861572 zł; przestępstwa skarbowe z kodeksu karnego skarbowego na kwotę 344692453 zł; oszustwa ubezpieczeniowe, wyczerpujące dyspozycję art. $286 \S 1$ i 3 kk. (klasyczne oszustwo dot. ubezpieczenia) oraz art. 287 § 1-2 kk. (dot. oszustwa ubezpieczeniowego komputerowego) i art. 298 kk. - oszacowane zostały na kwotę 15017631 zł. W 2005 r. wartość skumulowanych strat z tytułu przestępstw ubezpieczeniowych - według statystyk policyjnych - była jeszcze mniejsza i wyniosła 11932544 zł, czyli o 3085087 zł mniej niż w 2004 r. Co charakterystyczne w tym przypadku, wartość oszustw ubezpieczeniowych w 2003 r. określono w statystykach policyjnych na kwotę 9949769 zł

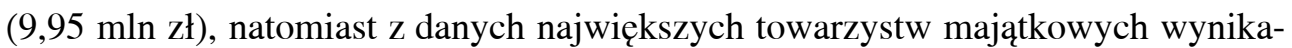
ło, iż w 2003 r. ujawniono 4115 przestępstw o łącznej wartości 65,7 mln zł. ${ }^{5} \mathrm{~W}$ odniesieniu do wartości wypłaconych odszkodowań w 2003 r. całego działu II (ubezpieczenia majątkowe), która wyniosła 7,6 mld zł przy zebranej składce 13,6 mld zł, wartość ujawnionych przez firmy ubezpieczeniowe przestępstw stanowiła i tak zaledwie $0,86 \%$ wartości wypłaconych odszkodowań i świadczeń działu II. Dlaczego zaledwie? Otóż dlatego, że szacuje się, iż wartość nienależnych odszkodowań i innych świadczeń w Polsce utrzymuje się na poziomie 20-30\% wypłacanych odszkodowań i innych świadczeń.

Podobnie w odniesieniu do przestępstw prania pieniędzy, w stosunku do których Departament Stanu USA określił, iż w 1998 r. przedmiotem prania w Polsce były dochody o wartości 8 mld dolarów USA (wg CBŚ w 2004 r. - 1120231769 zł). Z kolei wg badań Financial Action Task Force (FATF) Polskę sklasyfikowano w 1998 r. na 16. miejscu ze wskazywaną, jako wygenerowaną z przestępstw, kwotą 19,7 mld dolarów.

Jaka jest zatem skuteczność zwalczania zorganizowanej przestępczości, w tym przestępczości gospodarczej?

$4 \quad$ Z kolei według CBŚ KGP, wartość środków płatniczych nielegalnie wprowadzonych do obrotu w 2004 r. wyniosła 1120231769 zł; zob. Informacja CBŚ KGP dotycząca zwalczania przestępczości zorganizowanej w 2004 r.; Raport statystyczny 2004.

5 Rozbieżności te wynikają z odmiennego kryterium kwalifikowania czynów jako przestępstw ubezpieczeniowych. Zakłady ubezpieczeń stosują rozszerzoną formułę, kwalifikując jako przestępstwo ubezpieczeniowe m.in. przywłaszczenie składek przez agentów ubezpieczeniowych bądź pracowników zakładów ubezpieczeń czy też inne czyny. Za przestępstwo ubezpieczeniowe zakłady ubezpieczeń przyjmuja wszelkie czyny godzące bezpośrednio bądź pośrednio w interesy zakładów ubezpieczeń, natomiast organy ścigania stosują kwalifikację wg art. 298, 286 i 287 Kodeksu karnego. 
Wydaje się, iż aby odpowiedzieć na tak postawione pytanie, należy przeanalizować dwie podstawowe wielkości, jak liczbę likwidowanych grup przestępczych oraz liczbę prowadzonych i zakończonych postępowań (zob. tab. 5 i 6).

Tabela 5. Liczba zorganizowanych grup przestępczych wg CBŚ KGP

\begin{tabular}{|c|c|c|c|c|c|c|c|c|}
\hline Grupy / Rok & 2008 & 2007 & 2006 & 2005 & 2004 & 2003 & 2002 & 2001 \\
\hline Liczba grup istniejących & 425 & 348 & 246 & 296 & 262 & 351 & 522 & 485 \\
\hline Grupy wyeliminowane & 159 & 179 & 143 & 139 & 179 & 250 & 244 & b.d. \\
\hline
\end{tabular}

Źródto: opracowanie własne na podstawie danych CBŚ KGP - raporty statystyczne.

$\mathrm{Z}$ danych wynika, że mimo corocznego likwidowania dużej ilości grup przestępczych, mamy do czynienia w ostatecznym rachunku z przyrostem liczby zorganizowanych grup. W latach 2002-2003 odnotowano znaczny stopień wyeliminowania grup przestępczych (240 i 250), następnie obserwujemy spadek liczby likwidowanych grup do 159 w 2008 r. Natomiast w latach 2006-2008 odnotowujemy wzrost liczby grup przestępczych aż z 246 w roku 2006 do 425 w roku 2008.

Tabela 6. Liczba spraw procesowych CBŚ KGP

\begin{tabular}{|c|c|c|c|c|c|c|}
\hline Sprawy / Rok & 2008 & 2007 & 2006 & 2005 & 2004 & 2003 \\
\hline Liczba spraw procesowych & 1931 & 867 & 719 & 748 & 651 & 591 \\
\hline Sprawy przejęte z innych jednostek & 68 & 140 & 99 & 147 & 130 & 55 \\
\hline Sprawy podjęte z zawieszenia & 64 & 71 & 77 & 79 & 58 & 34 \\
\hline Sprawy wszczęte na podst. własnych materiałów & 178 & 227 & 167 & 261 & b.d. & b.d. \\
\hline Sprawy zakończone & 1106 & 1090 & 916 & 1039 & 910 & 785 \\
\hline
\end{tabular}

Źródto: opracowanie własne na podstawie danych CBŚ KGP - raporty; b.d. - brak danych.

Odnotowuje się wzrost liczby spraw procesowych prowadzonych przez CBŚ, szczególnie w 2008 r. w stosunku do 2007 (wzrost o 122\%), przy jednoczesnym stałym poziomie ich zakończeń (na poziomie 1 tysiąca rocznie). Jednocześnie wydaje się, iż występuje niski stopień wszczynania spraw na podstawie własnych materiałów operacyjnych (261 w 2005 r., 178 w 2008 r.), biorąc np. pod uwagę, iż w 2008 r. wszczęto 1064 sprawy .

$6 \quad$ Zob. Stan realizacji zadań Centralnego Biura Śledczego KGP w zakresie zwalczania przestępczości zorganizowanej w roku 2008 w ujęciu statystycznym; Raport statystyczny 2008. 
Poza omówionymi zagadnieniami pozostają jeszcze dwie bardzo istotne kwestie, jak wartość szacowanych strat wskutek zorganizowanej przestępczości oraz wartość odzyskiwanego mienia. W analizie tych danych uwzględniono rok 2003 i 2004 z uwagi na to, że od roku 2005 nie podaje się w Informacjach szacunkowej wartości strat. Podobnie, jeżeli chodzi o wartość odzyskiwanego mienia stwierdza się brak danych z lat 2005-2007.

Według danych CBŚ KGP w 2003 r. Skarb Państwa poniósł szacunkowe straty na kwotę 6399878915 zł (6,399 mld zł), w tym należy wyróżnić:

- wyłudzenia mienia, kredytów i dokonanie innych oszustw finansowych na szkodę Skarbu Państwa w wysokości 1246754549 zł,

- wyłudzenia nienależnego podatku VAT na kwotę 5153124366 zł $^{7}$.

Ponadto ustalono straty w wysokości 2719112204 zł na rzecz prywatnych przedsiębiorców na skutek wyłudzeń mienia, kredytów i dokonania innych oszustw.

Łączne szacunkowe straty z tytułu przestępstw w 2003 r. wyniosły 9118992 119 zl, natomiast odzyskano mienie w wysokości 17753979 zł 0,19\% szacunkowych strat ogółem.

Analogicznie w roku 2004 szacunkowe straty dla Skarbu Państwa w kwocie 801097801 zł, w tym na kwotę 649395995 zł wyłudzenia mienia, kredytów i inne oszustwa finansowe na szkodę Skarbu Państwa oraz 151701806 zł - wyłudzenia nienależnego podatku VAT. Ponadto - 214937275 zł wyłudzenia mienia, kredytów i dokonanie innych oszustw na rzecz przedsiębiorców prywatnych. Łączna wartość strat, czyli dla Skarbu Państwa i prywatnych przedsiębiorców wyniosła 1016035 076 zł, natomiast wartość odzyskanego mienia w tym roku wyniosła 14464413 zł ${ }^{9}$, co stanowiło 1,42\% szacunkowych strat ogółem.

Tabela 7. Mienie odzyskane przez CBŚ KGP

\begin{tabular}{||c|c|}
\hline Rok & Wartość mienia odzyskanego (w PLN) \\
\hline 2008 & 26055211,00 \\
\hline $2005-2007$ & brak danych \\
\hline 2004 & 14464413,00 \\
\hline
\end{tabular}

7 Informacja dotycząca zwalczania zorganizowanej przestępczości przez Centralne Biuro Śledcze Komendy Głównej Policji w Warszawie w 2003 r.; Raport statystyczny 2003.

$8 \quad$ Ibidem.

9 Informacja dotycząca zwalczania zorganizowanej przestępczości przez Centralne Biuro Śledcze Komendy Głównej Policji w Warszawie w 2004 r.; Raport statystyczny 2004. 


\begin{tabular}{|l|c|}
\hline 2003 & 17753979,00 \\
\hline 2002 & 50487154,00 \\
\hline 2001 & 139436497,00 \\
\hline
\end{tabular}

Źródto: CBŚ KGP - raporty statystyczne.

Z danych w zakresie wartości odzyskiwanego mienia wyraźnie obserwuje się tendencję malejącą w latach 2000-2004 (zob. tab. 7). Dopiero w 2008 r. odnotowano $80 \%$ wzrost wartości odzyskiwanych w stosunku do 2004 r.

Rozpatrując całokształt przedstawionych zagadnień, wydaje się, iż można postawić tezę o stosunkowo niskiej wykrywalności przestępstw gospodarczych, co znajduje również potwierdzenie w opiniach badanych przedsiębiorców ${ }^{10}$. Także kwestia wartości odzyskiwanego mienia nasuwa podobne wnioski.

Uzasadnia to tezę o konieczności modyfikacji systemowych, legislacyjnych, proceduralnych celem zasadniczej poprawy skuteczności zwalczania tych kategorii przestępstw. Istnieje bowiem wiele organów, które w ustawowe zadania mają wpisane wykrywanie i zwalczanie przestępstw ekonomicznych, narkotykowych, korupcyjnych, przestępstw przeciwko dobrom kultury i innych, natomiast problemem wydaje się być kwestia, czy zbyt duży zakres zadań (ich rozproszenie) nie odbija się negatywnie na skuteczności.

\section{Wnioski, prognoza}

Rozwój i kierunki zorganizowanej przestępczości są uzależnione od sytuacji społeczno-politycznej i ekonomicznej. Z jednej strony stabilizacja, uszczelnianie prawa, określony stopień wykrywalności przestępstw, a również ustabilizowany stopień zagrożenia. Z drugiej strony - konflikty społeczne, również na tle sytuacji ekonomicznej (kryzys gospodarczy, bezrobocie), spory i przetargi polityczne, koncentracja uwagi na innych zagadnieniach, wywołują przekonanie o mniejszej kontroli społecznej, w tym kontroli formalnej ze strony organów ścigania, wymiaru sprawiedliwości, mediów.

Rozwój przestępczości zorganizowanej skutkuje zagrożeniem dla bezpieczeństwa publicznego i interesów ekonomicznych Państwa. Zauważalne są zmiany

10 Zob. Badania sondażowe firmy Deloitte we współpracy z Bankiem Światowym i International Business Leaders Forum. Celem badań było zapoznanie się z opiniami na temat postrzegania nadużyć gospodarczych. Niemal wszyscy badani (94\%) wskazali na nieskuteczność wymiaru sprawiedliwości w walce z nadużyciami gospodarczymi, jedynie $7 \%$ wskazało organy ścigania jako sposób wykrywania nadużyć gospodarczych (70\% wskazało rutynowe działania nadzorcze kierownictwa firmy, 42\% - informacje od pracownika, 31\% - audyt wewnętrzny, $20 \%$ - przypadek $\mathrm{i}$ in.). 
w strukturze popełnianych przestępstw, w tym szczególnie groźne z użyciem technologii komputerowych.

Do ogólnych przyczyn zagrożeń należy zaliczyć:

1) ogólną sytuację społeczno-ekonomiczną i polityczną, charakteryzującą się znacznym zróżnicowaniem pozycji materialnej społeczeństwa oraz pauperyzacją wielu grup społecznych i zawodowych, wysoki poziom bezrobocia,

2) niespójność poczynań i brak realnej, efektywnej współpracy wszystkich organów ochrony porządku prawnego,

3) niewydolność systemu wymiaru sprawiedliwości (m.in. przewlekłość procesów sądowych w sprawach cywilnych i karnych),

4) niedoskonałości i nieskuteczność przepisów obowiązującego prawa w niektórych dziedzinach,

5) niedoskonałości procedur administracyjno-prawnych.

W zakresie przestępczości transgranicznej wśród zagrożeń można wskazać w szczególności:

1) zorganizowany przemyt środków odurzających i substancji psychotropowych,

2) rosnący stopień zorganizowania przerzutu ludzi i przemytu towarów oraz wzrost przemytu towarów objętych akcyzą,

3) funkcjonowanie w pobliżu przejść granicznych kryminogennych miejsc nielegalnego handlu, mających również wpływ na rozwój zjawisk patologicznych w sferze gospodarczej i społecznej.

W zakresie przestępczości finansowej i gospodarczej do głównych zagrożeń wskazać należy:

1) mający charakter międzynarodowy proceder prania brudnych pieniędzy (wzrastająca liczba ujawnianych przestępstw),

2) przestępstwa podatkowe, zwłaszcza związane $\mathrm{z}$ wyłudzeniami podatku VAT,

3) wszelkie działania na szkodę konsumentów (wprowadzanie do obrotu towarów nielegalnego bądź nieznanego pochodzenia, towarów niebezpiecznych dla zdrowia itp.),

4) funkcjonowanie ,szarej strefy” i innych patologii związanych ze sferą ekonomiczną,

5) nieprawidłowości w wydatkowaniu środków publicznych. 


\section{Kierunki działań}

Do głównych kierunków działań mających na celu poprawę efektywności zapobiegania i zwalczania zorganizowanej przestępczości gospodarczej należy wskazać:

1. Dalsze, intensywne prowadzanie działań w zakresie zapobiegania i zwalczania procederu prania brudnych pieniędzy. Przestępstwo legalizacji środków finansowych pochodzących z popełnianych przestępstw ma obecnie charakter ogólnoświatowy oraz stanowi swoisty i istotny mechanizm stymulujący dla zorganizowanej przestępczości. Przestępstwo to jest aktualnie jednym $\mathrm{z}$ bardziej istotnych zagrożeń dla sprawnego funkcjonowania systemów bankowych, które niewłaściwie zabezpieczone mogą stać się przedmiotem działalności ponadnarodowych grup przestępczych.

2. Zintensyfikowanie działań w zapobieganiu i zwalczaniu przestępstw związanych z wyłudzeniami podatku VAT, oszustwami i wyłudzeniami na szkodę sektora bankowego i ubezpieczeniowego oraz na szkodę legalnie działających podmiotów gospodarczych.

3. Zintensyfikowanie działań w zakresie zwalczania szeroko rozumianej przestępczości komputerowej (w tym popełnianej przy pomocy internetu).

4. Dalsze prowadzenie działań w zakresie zwalczania piractwa fonograficznego, komputerowego, kradzieży znaków towarowych, usuwania lub fałszowania oznaczeń towarów.

5. Zwiększenie skuteczności w zakresie kontrolowania obrotu towarowego pod kątem oszustw na szkodę konsumentów, wprowadzania do obrotu towarów nielegalnego bądź nieznanego pochodzenia, fałszowania znaków towarowych, prowadzenia działalności handlowej, produkcyjnej i usługowej.

6. Przeciwdziałanie nielegalnemu zatrudnieniu (także migracja tranzytowa oraz nasilająca się pobytowa) i naruszaniu praw pracowniczych.

Odrębnego potraktowania wymaga problematyka stworzenia ponadresortowej instytucji zajmującej się przepływem informacji dotyczących przestępstw gospodarczych. W walce ze zorganizowaną przestępczością gospodarczą kluczowe znaczenie ma dysponowanie przez organy ścigania jak największym zasobem informacji. Powinien istnieć system przepływu informacji, sygnalizujących zarówno konkretne działania przestępcze, jak i sytuacje mające charakter patologiczny, sprzyjający zaistnieniu przestępstwa. Chodzi o system przepływu informacji między instytucjami, szczególnie tymi, które zajmują się ochroną interesów majątkowych Skarbu Państwa oraz ochroną rynku finansowego (centralne urzędy nadzoru). 
Jednak nie tylko powołanie nowej instytucji powinno być sposobem walki z przestępczością. Niezbędne jest wyposażenie takiej centralnej instytucji (centralnego systemu informatycznego) w stosownie szerokie uprawnienia dostępu do komputerowych baz danych.

Skuteczne zwalczanie zorganizowanej przestępczości gospodarczej zależy od systemu i struktury administracji ekonomicznej i kontroli, a także wymaga dobrego ich funkcjonowania. Niewydolność któregoś z tych systemów powoduje, że znacząca liczba przestępstw gospodarczych nie zostanie wykryta.

Można stwierdzić, iż tylko wszechstronne i komplementarne działania podejmowane przez różnego rodzaju instytucje, funkcjonujące zarówno w zakresie ścigania przestępstw gospodarczych, jak i administracji gospodarczej i kontroli, w obrocie gospodarczym mogą doprowadzić do skutecznej eliminacji zjawisk przestępczych oraz patologicznych.

Skuteczność zwalczania zorganizowanej przestępczości pozostaje w ścisłej relacji z prawnymi możliwościami działania. Niektóre z nich, zwłaszcza o charakterze proceduralnym, wymagają usprawnień. Stosowanie odpowiednich instrumentów prawnych nie może charakteryzować się złożonością proceduralną. Chodzi w szczególności o skrócenie drogi w procesie decyzyjnym, tak aby zapewnić operatywność i szybkość działania. 


\section{SUMmarY}

Defining organized crime is not easy because it is continually changing; altering its activities and methods to the prevailing social conditions. Statistics obtained by the Polish Central Bureau of Investigation show the number of groups responsible for organised crime and that the number of socio-economically related crimes has increased.

This paper examines organized crime and the areas of society that it threatens. The different types of organised crime are defined as are the methods they use. How legislation is used to attempt to limit socio-economic crime is also examined. 